ISSN 2078-6441. Вісник Львівського університету. Серія географічна. 2013. Випуск 44. С. 17-23. Visnyk of the Lviv University. Series Geography. 2013. Issue 44. P. 17-23.

$631.482(210.7)(262.5)(477.74)$

\author{
росл в іл нчин, рин еонідов \\ деський н ціон льний університет імені . . ечников , \\ вул. ворянськ, 2, 65082, м. дес, кр їн
}

підст ві результ тів дослідження природних чинників грунтоутворення н о. міїний, їхніх геогр фо-генетичних особливостей і ролі в грунтоутворенні з'ясов но грунтотворний потенці л клім ту т тмосферно-хімічних умов території, щільних силік тних порід поверхні остров , рельєфу т біологічного чинник грунтоутворення. отенці л біологічного чинник $€$ визн ч льним в утворенні н острові незвично високогумусних (до 10-15\% гумусу і більше) і 6 г тих NPK чорноземних грунтів, потужність профілю й типово чорноземні вл стивості яких $з$ ч сом зрост ють доверху.

лючові слов : острів міїний, грунтотворний потенці л природних чинників грунтоутворення.

гідно з ученням . окуч єв , грунт - це особливе природно-історичне утворення, результ т скл дної і трив лої вз ємодії клім ту, м теринської породи (підгрунтя), рослинних і тв ринних орг нізмів т рельєфу впродовж віку (ч су) грунтоутворення.

ині до цих п'яти природних чинників грунтоутворення долучено чинник нтропогенного впливу н процес грунтоутворення, грунт і грунтовий покрив території. ідповідно, кожен із перелічених чинників зд тний сумісно з іншими утворюв ти грунт (грунтове тіло з . ргульяном). цьому р зі кожному із чинників н леж тиме певн ч стк внеску в м тері льну основу т дин міку процесу утворення, функціонув ння й еволюції грунту. ля оцінки ступеня зд тності чинник утворюв ти грунт, ч стки внеску його в м тері льну основу т дин міку грунтоутворення . ргульян у 1982 р. [15], н д лі зі спів втор ми [3, 16], . л зовськ т . енн дієв [4] з пропонув ли поняття “грунтотворний потенці л природних чинників грунтоутворення". озуміють зд тність (можливість) чинник формув ти грунт і грунтовий покрив з будьякого твердоф зового субстр ту. втори оцінили в 3 г льних рис х грунтотворний потенці л клім ту і біоти (flux-factors), м теринських порід як вихідного субстр ту (site-factor) т рельєфу місцевості (site-factor). озглянуто різні в рі нти ре ліз ції грунтотворного потенці лу природних чинників: профільно-горизонтний (результ т поєдн ння ч сткових потенці лів формув ння морфологічної структури і вл стивостей грунту), мінер лого-тр нсформ ційний (з ступенем тр нсформ ції мінер логічного і гр нулометричного скл ду вихідної породи), орг но-профільний (ре ліз ція орг нокумулятивної функції грунтів) т ємнісно-сорбційний (зіст влення ємності к тіонного обміну грунтів з теоретично можливою).

ед вно . их йлюк [9] з пропонув в концепцію грунтотворного режиму теритоpiї ( ), як д є змогу н лізув ти і моделюв ти не тільки окремі процеси бо дії чинників природно-геогр фічного середовищ н процеси i грунти, й цілісно функціонув льну їхню систему. $є$ комплексом (п р генезою) грунтотворних

(C) іл нчин ., еонідов ., 2013 
потенці лів чинників грунтоутворення, грунтотворних процесів т грунтових ч сових к тен території, який зумовлює комплекс елемент рних грунтових процесів, структуру грунтового покриву, тренд розвитку окремих грунтів і структури грунтового покриву, п р генез компонентів системи і підсистем тощо.

світлі сх р ктеризов них вище н пр цюв нь 3 пит ння оцінки грунтотворного потенці лу природних чинників грунтоутворення, результ тів проведеного впродовж 2003-2013 рр. дослідження природних чинників грунтоутворення н о. міїний, їхніх геогр фо-генетичних особливостей т ролі в грунтоутворенні $[2,7,8 \mathrm{~T}$ ін.] ми вперше спробув ли оцінити грунтотворний потенці л природних умов остров як чинників утворення тутешніх грунтів і грунтового покриву.

г д ємо, що відповідно до з г льновизн ного докуч євського положення, грунтоутворення - це трив лий і скл дний природний процес утворення грунту з гірської породи земної поверхні під впливом (дії) живих орг нізмів, продуктів їхньої життєдіяльності т розкл д ння і гуміфік ції відмерлих решток орг нізмів у певних умов $\mathrm{x}$ природно-геогр фічного середовищ . і ск з ного виплив $є$ висновок, що геологічний і біологічний чинники роблять н йбільший субст нтивний внесок у процес грунтоутворення. цьому р зі логічно пост є пит ння про зіст вність внесків цих двох чинників у м тері льну основу грунтоутворення. дже м с орг нічної речовини в декільк р зів менш від м си геологічної породи, т й зосереджен суттєво більш ч стин м си орг ніки у верхній ч стині грунтового профілю. мовірно, оцінюв ти рівень внеску цих м тері льних компонентів природного середовищ тільки з співвідношенням їхніх м с у певний момент процесу грунтоутворення непр вомірно. іч у тому, що мінер льні геологічні речовини поверхні емлі досить інертні, у процесі грунтоутворення їхня м с ч стіше не збільшується. одноч с м с щорічно продуков ної орг нізм ми речовини, н вП ки, регулярно н дходить у грунт і дин мічно н рост є т обновлюється, н йбільше - у верхній ч стині грунтового профілю т горизонті (ш рі) н земної підстилки. им зумовлений н йвищий вміст гумусу т орг нічного детриту с ме у верхніх горизонт х грунтів, зб г ченість їх нітрогеном т зольними елемент ми, у тім числі , Mg, , т ін. ч сом інтенсивніш є грунтотворн роль і вплив орг нічного чинник н морфологію, скл д і вл стивості утворюв ного під його дією грунту $[4,6,12]$.

стрів міїний з доволі специфічними умов ми природно-геогр фічного середовищ може слугув ти ілюстр цією визн ч льної ролі біологічного чинник в грунтоутворенні, н віть 3 умови близького з ляг ння від поверхні щільних силік тних порід т м лопотужної і к м'янистої кори їхнього звітрюв ння. ослідженнями попередніх років [1, 2, 7 т ін.] з'ясов но, що ділянки поверхні між виход ми щільних порід покриті степовою тр в'яною рослинністю дост тньо високої сум рної біом си, основн ч стк якої зосереджен у верхній ч стині грунтового профілю т н земному горизонті степової повсті. ісля відмир ння біом с тр в розкл д ється, в зн чній кількості й тр нсформується у гумусові речовини, що й зумовлює утворення незвично високогумусних (до 10-15\% гумусу і більше) чорноземних грунтів, потужність яких з ч сом н рост є доверху. чим ліпші умови для розвитку тр в'яної рослинності з ступенем вологоз безпеченості й потужністю грунтового субстр ту, тим більше біом с тр в'яних фітоценозів, очевидніше збільшення гумусності й потужності чорноземних грунтів.

р зі розкл д ння тр в'яного оп ду вивільняються й елементи живлення рослин (зокрем , Ca, K, N, P, Mg т ін.), які систем тично н дходять у грунт і з луч ються до біологічного колообігу речовин. ч сом вміст їхній у грунті, як і гумусу, поступово 
збільшується. ожн зробити висновок, що незвично високий вміст у чорноземних грунт х остров гумусу і біофільних елементів $€$ результ том прогресивної їхньої кумуляції в процесі функціонув ння системи “тр в'ян рослинність-грунт”. ослини тут $\epsilon$ ктивним уч сником колообігу речовин $\mathrm{T}$ першопричиною інтенсифік ції процесу гумусо- і чорноземоутворення, біологіз ції профілю, речовинно-хімічного скл ду і вл стивостей грунтів. ірогідно, у перебігу цих процесів певну роль відігр є і послід численної н острові й тр нзитної орнітоф уни [1, 2, 10 т ін.], можливо, і біофільних елементів, що потр пляють н поверхню остров 3 тмосферними оп д ми і відкл деннями [8].

ищі зелені рослини вплив ють н грунт і грунтоутворення не тільки відмерлими орг нічними з лишк ми. е з життя вони продукують у грунт через ктивну ч стину коренів різні орг нічні і мінер льні компоненти - орг нічні кислоти, іони -, +, ${ }_{3}^{-}$, мінокислоти, ферменти, гелеподібні виділення тощо [5, 11, 14 т ін.]. підр хунк ми . оголєв [5], н створення 1 г орг нічної речовини тр в'янисті рослини поглин ють з грунту від 0,95 до 2,00 ммоль к тіонів, отже, стільки ж протонів + десорбують у грунт, які ктивно змінюють його мінер льну основу.

визн чення сутності грунтотворення, н веденого н поч тку ст тті, виплив є, що м теринські породи - другий з зн ченням (після біологічного) чинник грунтоутворення. е м тері льн основ грунту т процесу його утворення. процесі грунтоутворення м теринські породи з зн ють прямого чи опосередков ного впливу (дії) рослинних, тв ринних і мікроорг нізмів, клім тично-гідрологічних і тмосферно-хімічних чинників, що призводить до їхньої тр нсформ ції в горизонти грунтового профілю т педосфери суші [4, 6, 12, 13 т ін.]. , безперечно, щільність, х р ктер зложення, речовинно-хімічний скл д і вл стивості м теринських порід н кЛ д ють відбиток н процес утворення і морфолого-генетичні особливості сформов них н цих пород х грунтів. ід м теринських порід грунти усп дковують гр нулометричний, хімічний мінер логічний скл д. ід скл ду і вл стивостей порід зн чно з леж ть фізичні, фізикохімічні т грохімічні вл стивості грунтів, утворених н цих пород х. грунтотворний потенці л м теринської породи (підгрунтя), з визн ченням . ргульян зі спів вт. [3, $15,16]$, оцінюють зд тністю породи тр нсформув тися в нове орг но-мінер льне утворення з новим скл дом і вл стивостями, нові структури, утворюв ні в процесі педогенези.

онкретніше щодо грунтотворної ролі т потенці лу м теринських порід в умов х о. міїний. ихідними (м теринським) пород ми для грунтоутворення тут слугує м лопотужний щебенюв то-к м'янистий елювій чи елюво-делювій щільних силік тних (кислих) порід зн чної міцності. ною перепоною для формув ння н острові потужної кореневої системи рослин, відповідно, і повнорозвинених повнопрофільних грунтів. ут утворилися чорноземи неповнорозвинені й чорноземи короткопрофільні з потужністю гумусов ного профілю до 25 і 25-45 см, відповідно, н ділянк $\mathrm{x}$ близького 3 ляг ння від поверхні (до 10-12 см) щільних порід - грунти примітивні $[1,2]$. собливостями скл ду і вл стивостей м теринських порід зумовлен низк геогр фо-генетичних особливостей морфології, речовинно-хімічного скл ду і вл стивостей утворених н них грунтів: їхня нек рбон тність, щебенюв тість-к м'янистість т кислотність, що посилюються донизу по профілю, бідність н основи, домінув ння в скл ді гумусу фр кції -1 м йже без фр кції -2. оверху по профілю грунтів, з посиленням біологіз ції їхнього скл ду і вл стивостей, вплив вихідних порід поступово посл блюється. 
одо оцінки впливу м теринських порід остров н утворення грунтів і грунтового покриву з зн чимо ще т ке. зв'язку із повсюдними виход ми н денну поверхню щільних порід т їхніх грубоул мкових розсипів грунтово-рослинний покрив остров лок льно-фр гмент рний 3 різною просторовою потужністю грунтових профілів 3 лежно від глибини з ляг ння від поверхні щільних порід $[1,2]$. ильн к м'янистість кори звітрюв ння і сформов них н ній грунтів зумовлює дуже високу їхню водопроникність і низьку вологоємність i, як н слідок, - швидку зміну поверхневого стоку води н підгрунтовий. підсумку делюві льні, зн чно й ерозійні процеси н острові під покривом тр в'яної рослинності м лоінтенсивні, підгрунтовий стік швидкоплинний і лише після вип д ння рясних дощів т снігот нення.

лім т т тмосферно-хімічні умови території вплив ють н грунт і грунтоутворення як безпосередньо, зумовлюючи рівень енергетичного з безпечення і гідротермічний режим грунту, т к і опосередков но, вплив ючи н інші чинники грунтоутворення $\mathrm{i}$ л ндш фтно-геохімічну ситу цію 3 г лом (процеси л ндш фтно-геохімічної мігр ції хімічних елементів і речовин, м теринські породи т їхнє звітрюв ння, рослинність і життєдіяльність орг нізмів тощо). 3 клім тичних т тмосферно-хімічних умов території в жливими для л ндш фто- і грунтоутворення є променев енергія сонця, кількість тмосферних оп дів т їхній хімічний скл д, м с $\mathrm{T}$ хімічний скл д сум рних (сухих і вологих) тмосферних відкл день н земну поверхню. грунтотворний потенці л клім то- тмосферно-хімічного чинник, у світлі н укових ідей т висновків

ргульян зі спів вт. $[15,16]$, визн чений зд тністю цього чинник через процеси звітрюв ння і грунтоутворення, мігр ції хімічних елементів і речовин перетворюв ти вихідну м теринську породу в повнорозвинений грунт певних речовинно-хімічного скл ду, вл стивостей і рівня родючості.

умов х о. міїний клім тичний т тмосферно-хімічний чинник л ндш фто- і грунтоутворення, як з зн чено у [7], вирізняється низкою специфічних особливостей. ерш $з$ все, тмосферні оп ди - це єдине джерело вологоз безпечення н острові, оскільки горизонту підгрунтових вод тут нем . ічн кількість оп дів тут менше 300 мм, вир зн середземноморськ ритмік їхнього вип д ння. ологоз безпеченість території з тмосферних оп дів явно недост тня 3 високої з безпеченості тепловими ресурс ми. орічн сезонн змінюв ність вологого і посушливого періодів сприятлив для процесів гумусоутворення і гумусон копичення під степовою тр в'яною рослинністю т формув ння н острові грунтів с ме чорноземного типу. порівняно вологий і теплий весняно-р нньолітній період дост тньо інтенсивні процеси мінер ліз ціїгуміфік ції оп ду тр в'яної рослинності. період літньо-осінньої посушливої погоди процеси гуміфік ції орг нічного оп ду сповільнюються, новоутворені гумусові речовини дегідр туються, ко гулюють і н копичуються у верхніх горизонт х профілю грунтів.

поверхню остров пр ктично цілорічно з тмосферними оп д ми т тмосферними відкл деннями, т кож безпосередньо з моря (імл, бризки, пін ) н дходять морські солі (головно хлориди і сульф ти н трію), т кож біофільні елементи і речовини. н слідок цього грунти остров різною мірою з солені й солонцюв ті, особливо в періоди бездощів'я. пряжені дослідженя хімічного скл ду тмосферних оп дів і відкл день т вод підгрунтового стоку д ють підст ви стверджув ти, що солі, зн чною мірою і біофільні елементи, які потр пляють н поверхню остров , з низхідними плин ми вологи н дходять н підгрунтовий стік. обто л ндш фтно- і грунтовогеохімічн роль вод тмосферних оп дів головно тут зводиться до винесення солей 3 
межі грунтово-підгрунтової товщі, іншими слов ми, - до ролі природного знесолюв льного меліор тор л ндш фтів, включно і грунтів остров .

н решті про грунтотворний потенці л рельєфу остров - перерозподілюв ч потоків вологи і тепл т продуктів звітрюв ння й грунтотворення, - його оцінюють зд тністю створюв ти м ксим льну різном нітність грунтових вл стивостей, горизонтів і профілів, тобто це м ксим льно різном нітний у просторі грунтовий покрив в умов х певних клім ту і м теринських порід $[3,6,16]$. зн чимо, що в рельєфі остров вирізняють п'ять геоморфно-гіпсометричних рівнів (зон) поверхні - вершинновододільного пл то, схилів ухилом до 3-5 (6) ${ }^{\circ}$, делюві льно- кумулятивних підніж схилів т днищ улоговин у північній ч стині, д вніх морських тер с т узбережних крутосхилів і урвищ висотою до 20-27 м [7]. івнево-геоморфні т експозиційні відмінності поверхні є причиною просторового перерозподілу тмосферної вологи, формув ння поверхневого і підгрунтового стоку, відповідно, і мігр ції т кумуляції хімічних елементів і речовин від гіпсометрично вищих до нижчих рівнів поверхні. ідповідно, просторово диференціюється л ндш фтно-геохімічне i грунтотворне середовище, що спричиняє диференці цію грунтово-рослинного покриву, речовиннохімічного скл ду, вл стивостей і біопродуктивності грунтів остров .

роілюструємо це н рисунку грунтово-рослинно-оролітологічним профілем -5 протяжністю 65 м у північній ч стині остров н схилі північної експозиції, ускл дненому улоговин ми відносною глибиною до 3-5 (7) м. к 6 чимо із рисунк , н йліпші з рельєфом умови для розвитку тр в'яної рослинності т утворення чорноземних грунтів остров н делюві льно- кумулятивних підніжжях схилів $\mathrm{T}$ днищ х улоговин і виположених знижень, куди н дходить дод тков (до тмосферної) волог із гіпсометрично вищих рівнів поверхні. ут і н йпотужніші чорноземні грунти в меж х остров - до 45-55, н днищ х улоговин - 65-75 cм. орівняно ліпшого тмосферного зволоження схили з хідної і північної експозицій, де т кож потужніший грунтоворослинний покрив порівняно зі східною, й особливо південною відносно сухішими ч стин ми території остров .

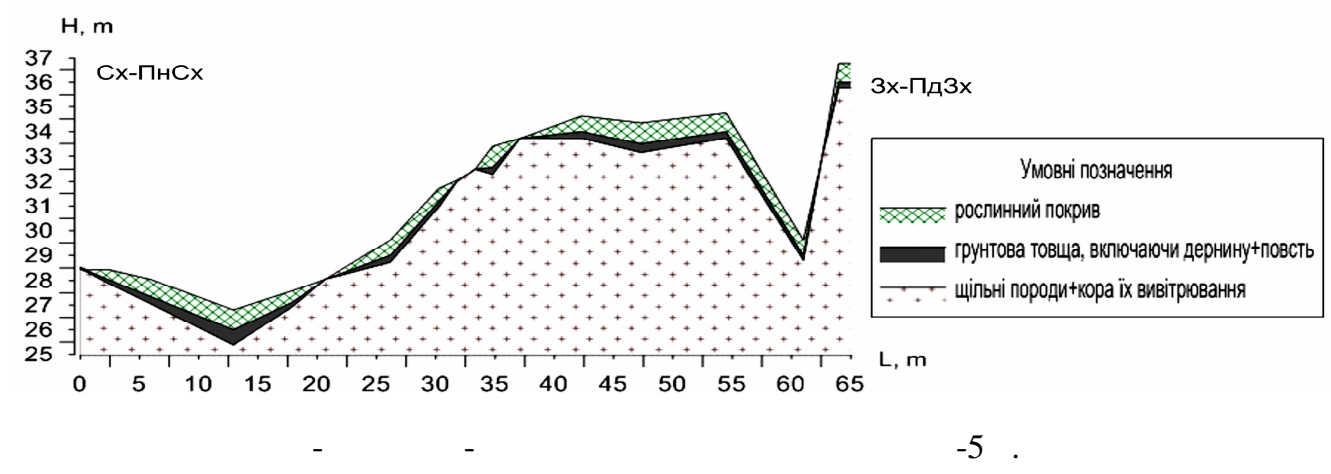

(м сшт б горизонт льний 1:500, м сшт б вертик льний 1:200)

тже, щодо пит ння про грунтотворний потенці л природних чинників грунтоутворення о. міїний висловимо т ке міркув ння. и сх р ктеризув ли оцінку грунтотворної ролі т потенці лу лише зовнішніх [3 9] чинників грунтоутворення - оролітології поверхні, біологічного чинник, клім ту т тмосферно-хімічних умов території. к з зн ч є . их йлюк [9], у р зі грунтоутворення в жливими є і внутрішні чинники, 
передусім речовинно-хімічний скл д і вл стивості грунтів (гр нулометричний, хімічний, мінер логічний скл д, гумусовий ст н, з соленість, скл д грунтовопоглин льного комплексу тощо). процесі грунтоутворення відбув ється їхня інтегр тивн вз ємодія, результ том якої є комплекс зовнішніх і внутрішніх чинників грунтових (елемент рних грунтових) процесів т особливості їхнього прояву в умов х конкретної території, й особливо у специфічних природних умов х о. міїний. огляду н це н веден вище оцінк потенці лу утворення грунтів і грунтового покриву остров лише 3 уч стю його природних умов - зовнішніх чинників грунтоутворення, безперечно, є попередньою і потребує под льшого дослідження т доопр цюв ння.

\section{СПИСОК ВИКОРИСТАНОЇ ЛІТЕРАТУРИ}

1. іл нчин . . орноземні грунти остров міїний / . . іл нчин // грохімія і грунтозн вство. - 2011. - ип. 76. - .95-100.

2. іл нчин . . ослідження грунтового покриву о. міїний / . . іл нчин, . . нт л й, . . ортик, . . уяновський // стрів міїний. біотичні х р ктеристики : моногр фія / [відп. ред. . . едінець; дес. н ц. ун-т ім. . . ечников ]. - дес : стропринт, 2008. - .54-79.

3. ер симов . . етодические подходы к к ртогр фической оценке клим т к к ф ктор почвообр зов ния / [ . . ер симов , . . лябин , . . русевск я, . . об , . . ргульян] // есник оск. ун-т. ерия 17. очвоведение. 2000. - № 4. - . 9-14.

4. $л$ зовск я . . еогр фия почв с основ ми почвоведения / . . л зовск я, . . енн диев. - . : зд-во оск. ун-т , 1995. - 400 с.

5. оголев . . урые горно-лесные почвы оветских рп т: втореф. дис. н соиск ние уч. степени доктор с.-х. н ук / . . оголев. - ., 1965. - 40 с.

6. орсунов . . едосфер емли / . . орсунов, . . p сех . - л н- дэ : зд-во , 2010.-472 с.

7. еонідов . . риродні умови остров міїний, їх роль у формув нні л ндш фтно- і грунтово-геохімічного середовищ / . . еонідов // ричорноморський екологічний бюлетень. - 2011. - № 1. - . 149-157.

8. едінець . . тмосферно-хімічні дослідження / . . едінець, . . едінець, . . рощенко // стрів міїний. біотичні х р ктеристики: [моногр фія; дес. н ц. ун-т ім. . . ечников ]. - дес : стропринт, 2008. - . 115-137.

9. их йлюк . . рунтоутворюючий режим території / . . их йлюк // гр рний вісник ричорномор'я. - 2004. - ип. 26, . 1. - . 183-191.

10. стрів міїний. ослинний і тв ринний світ: [моногр фія] / . . минтин , . . в ниця, . . удзенко [т ін.]; дес. н ц. ун-т ім. . . ечников .- дес : стропринт, 2008. - 182 с., [38] рк. іл.

11. етербургский . . грохимия и физиология пит ния р стений / . етербургский. - . : оссельхозизд т, 1971. -335 с.

12. озняк . . инники грунтоутворення : [н вч. посібник] / . . озняк, . . р сех . - ьвів : ,2007. -400 с.

13. очвоведение. очв и почвообр зов ние / [под ред. . . овды, . . оз нов ] / [ . . елицин , . . сильевск я, . . ришин и др.]. - .: ысш. шк., 1988. . 1. $-400 \mathrm{c}$. 
14. мцевич. . елеобр зные корневые выделения р стений и их действие н почву и корневую микрофлору / мцевич // етоды изучения продуктивности корневых систем и орг низмов ризосферы. еждун род. симпоз. 28 вгуст - 12 сентября 1968 г. - . : ук , 1968. - . 206-209.

15. ргульян . . звитие почв во времени / . . ргульян // роблемы почвоведения. - . . : ук , 1982. - . 108-113.

16. об . . очвообр зующий потенци л почвообр зующих ф кторов / . . об , . . ер симов , . . ргульян, . . русевск я [и др.] // енез , геогр фія т екологія грунтів : зб. н ук. пр ць іжн р. конф. ьвів, 16-18 вересня 1999 р. - ьвів, 1999. - .90-92.

m ття:н дійшл до ред кцї̈ 01.03.2013

доопр цьов н 03.04 .2013

прийнят до друку 17.06.2013

\title{
SOIL FORMATION POTENTIAL OF NATURAL SOIL FORMATION FACTORS OF ZMIINY ISLAND
}

\author{
Yaroslav Bilanchyn, Iryna Leonidova \\ Ilya Mechnikov National University of Odesa, \\ Dvorianska St., 2, UA - 65082, Odesa, Ukraine
}

The article assesses soil formation potential of several factors allocated on Zmiiny island, particularly the climate and atmospheric conditions of the territory, the solid silicate rocks from the island's surface, and the biological factors of soil formation. This assessment derives from analysis of the natural soil formation factors of Zmiiny island, their geo-genetic specifications and role in soil formation. The biological factor is crucial in formation of the uncommonly rich in humus (10-15\% of humus and more) and NPK rich chornozem soils which possess tendency to increase their chornozem properties and profile depth with time.

Key words: Zmiiny island, soil formation potential of the natural soil formation factors.

\author{
росл в ил нчин, рин еонидов \\ десский н цион льный университет имени . . ечников , \\ ул. ворянск я, 2, 65082, десс, кр ин
}

основ нии результ тов исследов ния природных ф кторов почвообр зов ния н о. меиный, их геогр фо-генетических особенностей и роли в почвообр зов нии определено почвообр зующий потенци л клим т и тмосферно-химических условий территории, плотных силик тных пород поверхности остров, рельеф и биологического ф ктор почвообр зов ния. отенци л биологического ф ктор является определяющим в обр зов нии н острове чрезвыч йно высокогумусных (до 10-15 \% гумус и более) и бог тых NPK черноземных почв, мощность профиля и типично черноземные свойств которых со временем н р ст ют кверху.

лючевые слов : остров меиный, почвообр зующий потенци л природных ф кторов почвообр зов ния. 